\title{
The Lima Bean: A Vegetable Crop for Processing
}

Ed Kec ${ }^{1}$, James L. Glancey ${ }^{2}$, and Tracy L. Wootten ${ }^{3}$

The lima bean (Phaseolus lunatus L.) is an important crop grown for canning and freezing in specific areas of the United States. Three types of lima beans are used for processing: the smallseeded baby type; the large-seeded Fordhook type; and the speckled bean type (Fig. 1). The predominant method of harvest is with podstripper combines (Fig. 2). In 1995, lima beans for processing were planted on 52,100 acres in the United States (USDA, 1996). Delaware plants more acreage (10,000 to 12,000 acres) annually for processing purposes than any other state (Tarburton et al., 1995) and on more acres than any other vegetable. Other major production areas for processing are California, Washington, Oregon, Wisconsin, Illinois, and Minnesota. In Tennessee and other isolated areas in the southern United States, speckled lima beans (butterbeans) are produced for canning and freezing. These speckled types are considered to be more heat tolerant than baby or Fordhook types. All three bean typesbaby, Fordhook, and speckled-are planted in Delaware commercially (Kee et al., 1996).

Although most lima beans grown in the United States are harvested fresh, dry lima beans are also grown. California is the only state that reports acreage for dry lima bean, with 23,000 acres of baby lima beans and 21,000 acres of large-seeded lima beans planted in 1995 (USDA, 1996). The largest share of the U.S. dry lima bean market is packaged for retail sale. Other significant markets for dry lima beans are for rehydrated products, often for canning purposes. Most of the California dry baby lima bean production is exported to Japan.

Dry lima beans are produced as a traditional pulse crop in many arid regions of the world. Madagascar and Peru have been leading centers of production. Lima beans are also produced for local use in Ecuador, the Philippines, India, and in the subhumid and humid tropics of Africa. Dry lima beans and their flour are excellent nutritional sources, containing about $20 \%$ protein and $65 \%$ carbohydrates (Lyman et al., 1985).

\footnotetext{
'Extension vegetable crops specialist IV, University of Delaware Research and Education Center, Georgetown, DE 19947.

${ }^{2}$ Assistant professor, Department of Agricultural Engineering, University of Delaware, Newark, DE 19711.

${ }^{3}$ Extension associate II-Vegetable crops, University of Delaware Research and Education Center, Georgetown, DE 19947.

Use of trade names does not imply endorsement of the products named nor criticism of similar ones not named. The cost of publishing this paper was defrayed in part by the payment of page charges. Under postal regulations, this paper therefore must be hereby marked advertisement solely to indicate this fact.
} 
The Central Valley of California is the major seed production center, with about 1000 acres. The arid conditions that exist as seeds mature enhances seed quality by reducing the incidence of seedborne diseases.

In Delaware, lima beans are considered to be a cornerstone crop of the vegetable processing industry. Because the state is one of the few areas that produce the crop, lima beans offer a unique item that local processors sell nationally. Lima beans are doublecropped on as much as three-fourths of Delaware's lima bean acreage, thus maximizing land use. They are often planted in June or July after peas (Pisum sativum L.) or small grains. This enhances the grower's competitive advantage while helping to ensure consistent supply for local processors.

Typically, the grower contracts with a processing company for a certain acreage. In most cases, the processing company performs the harvest and raw product delivery functions, although some growers own their own harvest equipment, in which case the processor pays a higher price for the lima beans. The same harvesting equipment is used for peas and lima beans, so capitalization costs can be spread over two crops per year.

The purpose of this article is to acquaint the reader with lima beans, identify examples of successful production improvements, and suggest further research issues. Improving profitability and efficiency are essential, not only to individual producers and processors, but to the enhancement of a competitive position for the vegetable processing industry.

\section{The lima bean plant}

Lima bean is native to tropical Central and South America. Guatemala is the general region of origin. Dispersal of the crop is thought to be due to Native American trade and travel. Lima beans were well established in the southwestern and southeastern United States before the early European explorers arrived. Although a tropical perennial in the wild, lima beans have been developed as

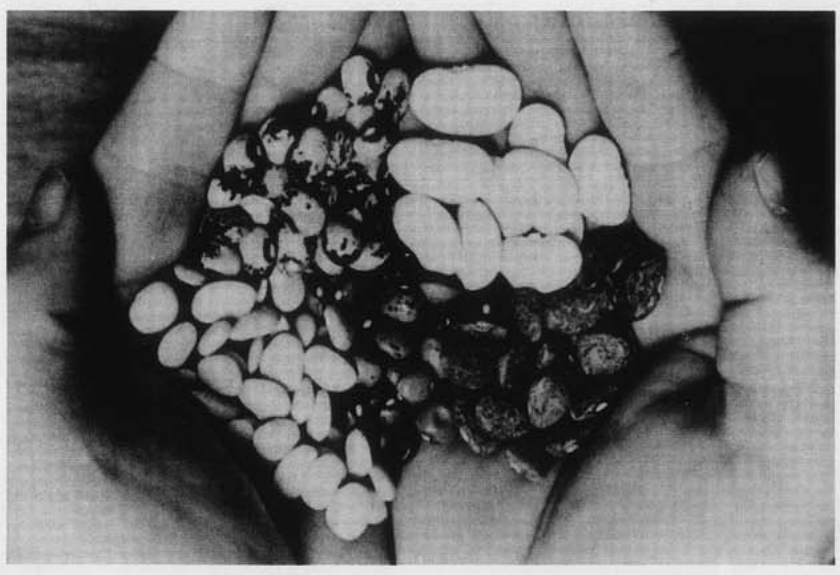

annuals for production in the United States. Wild lima beans probably supported themselves by climbing on other plants (Mackie, 1943). Indeterminate climbing varieties, known as pole beans because of the pole that supports their growth, are a popular item in home and garden market settings. Varieties developed for commercial production have a determinate habit. These smaller, bush types are necessary for mechanical harvest.

A significant fact about the lima bean's development still impacts the industry today. There are two major subgroups-MesoAmerican and Andean - that have genetically distinct DNA. Direct descendants of the Meso-American subgroup are the baby lima bean varieties, which exhibit more heat tolerance than Fordhook types, the descendants of the Andean group (Nienhuis, 1993). The cooler Andean conditions in the higher elevations would not require the development of heat tolerance necessary for adequate production in the Meso-American area.

Many factors influence yields, but weather conditions that affect flower bud development, pollination, and pod maturation have the most impact in Delaware (Kee, 1986). Low yields are associated with profuse abscission of flowers and developing pods. Low soil moisture, along with high temperatures and low relative humidity, lead to reduced pod set and retention (Andrews, 1935; Corder, 1933). These climatic stresses negatively affect pollen tube growth and fertilization. Unfertilized flowers abscise within 48 hours of the hooded bud stage. At least one ovule must be fertilized and begin development and prevent abscission (Lambeth, 1950). Temperatures of $90^{\circ} \mathrm{F}$ or above reduce pollination and pod set. Prolonged drought (7 days or more with less than 2 inches of water) also negatively affects yield (Fisher and Weaver, 1974). High humidity favors pollination and pod set and is one reason lima beans have been grown successfully in the coastal valleys of California (Hendry, 1918) and coastal areas of Delaware. Fogs, heavy dews, and their moderating effects on temperature are helpful to pollination and pod set. High night temperatures also adversely affect yields, because the plant's energy is consumed through respiration, limiting the plant's physiological ability to grow, set and retain pods (Fisher and Weaver, 1974).

Lima bean flowers are produced on an indeterminate raceme; three flowers appear at each node along the raceme (Fig. 3). Recent research conducted in Delaware identified important phenomena related to flowering. The two outer flowers at each node begin to develop simultaneously, while the middle flower lags in development. If one or both of the outer flowers abscised, the middle 

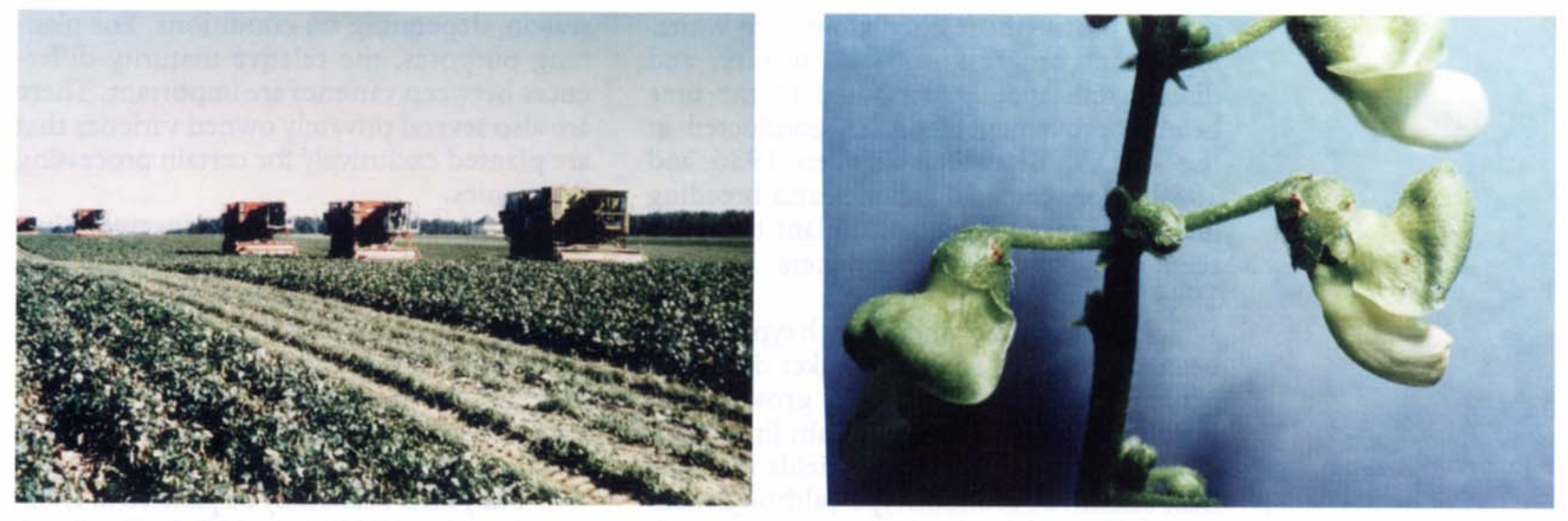

flower continues to develop, but at a greater rate than when the outer two flowers continued to develop (Fig. 4). New buds and flowers also appear and develop at the site of abscised flowers. In Delaware, this reflowering contributed very little to final yield, while concurrent studies in California found that reflowering accounted for up to $75 \%$ of the final pod set (Wootten, 1995). Lima bean yields in California (4000 lbs/acre) are consistently higher than those in Delaware (1800 lbs/ acre), in part due to reflowering. Night temperatures frequently fall into the $\mathbf{5 5}$ to $60^{\circ} \mathrm{F}$ range in the Central Valley of California, especially from Los Banos area northward. These cool nights in California play a role in allowing the plant to perform at higher efficiency. Interestingly, yields in Delaware generally increase with later planting dates,
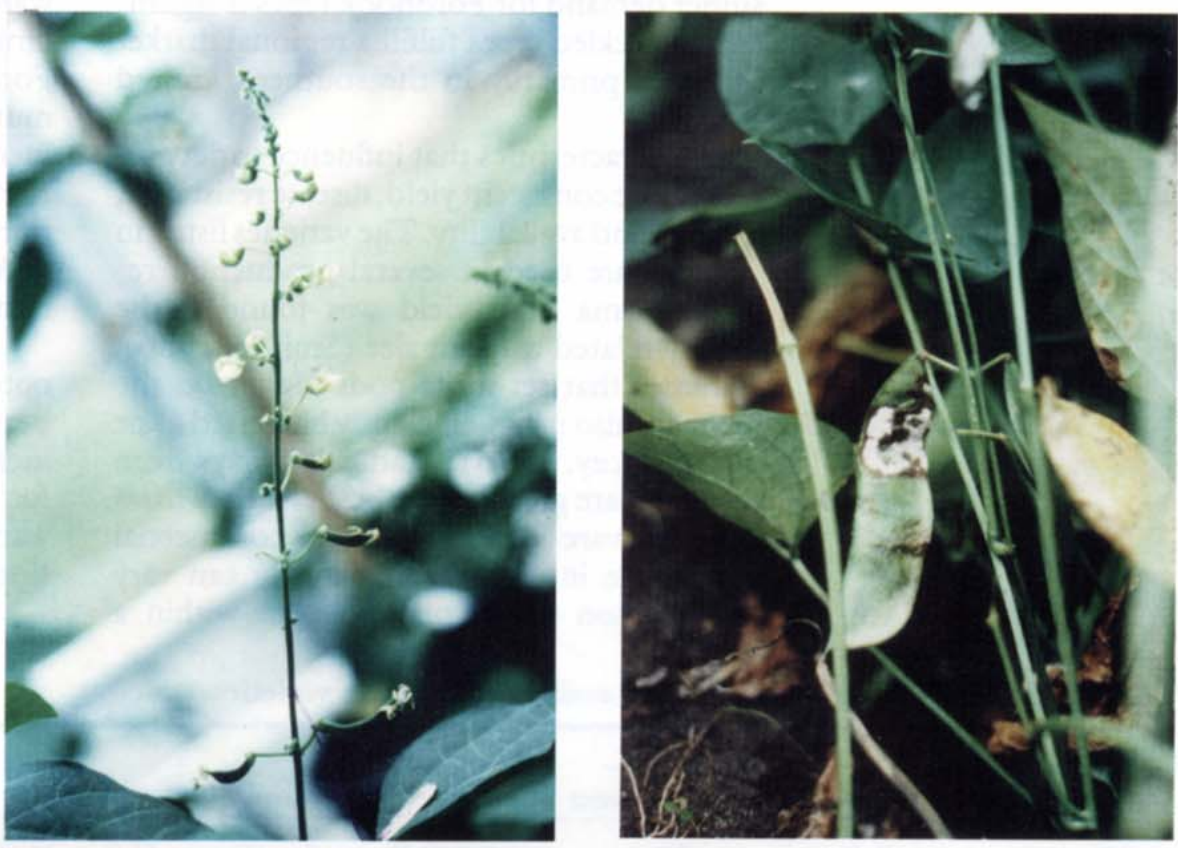
which corresponds to higher rainfall, cooler day and night temperatures, in September and October, when these later plantings are flowering and setting pods (Wootten, 1995).

Depending on variety, first flowering generally occurs 35 days from planting and peak flowering at 60 days. Harvest occurs from 80 to 90 days for baby varieties and 90 to 100 days for Fordhook varieties. A wide range of factors can influence maturity, including temperature, drought, and any environmental conditions that cause a prolonged flowering period, commonly described as split-set.

\section{Production practices}

Liming AND FERTILIzATION. Lima beans are legumes that may fix atmospheric nitrogen with the aid of nitrogen-fixing bacteria that live in their roots. This process is enhanced when the soil $\mathrm{pH}$ is in the range of 5.8 to 7.0.

Typically, 60 to $80 \mathrm{lbs} /$ acre of nitrogen is applied at planting. However, recent research indicates that lima beans may not

respond to fertilizer nitrogen in certain production areas, even on sandy soils (Sirait et al., 1994). The Univ. of Delaware recommendation for nitrogen has been lowered to $20 \mathrm{lbs}$ / acre for lima beans double-cropped after peas, another legume (Kee et al., 1996).

Phosphorous and potassium are supplied in fertilizers in amounts based on soil testing. At medium levels of fertility, $80 \mathrm{lbs} /$ acre of $\mathrm{P}_{2} \mathrm{O}_{5}$ and $120 \mathrm{lbs} /$ acre of $\mathrm{K}_{2} \mathrm{O}$ are recommended. There is no demonstrated need for minor element fertilization if soil $\mathrm{pH}$ is in the recommended range. This is especially true if the field has a history of cover crops or manure applications. The decomposition of these organic materials provide adequate levels of minor elements.

Variety selection. Lima bean varieties for processing purposes are all green-cotyledon types. These remain green through out maturity (Wester, 1965). Before discovery of genetically controlled cotyledon color, processors incurred a major expense in removing
Fig. 2. (top left) A typical commercial field of lima beans in Delaware, harvested by pod-stripper combines. Fig. 3. (lower left) Lima bean raceme with (from the top) buds, swollen buds (balloons), open flowers, and immature pods. Fig. 4. (top right) A lima bean flower set. The center bud is the second formed at that site, preparing to reflower. Fig. 5. (lower right)Downy mildew (Phytophthoraphaseoli) on lima bean. 
mature beans whose cotyledons turn white. Significant progress in yield, quality, and disease resistance is attributed to the lima bean improvement program conducted at the USDA, Beltsville, between 1936 and 1989. More than 30 varieties and breeding lines were made available to plant breeders, seed companies, and producers (Stavely, 1989).

Processors determine which type of lima beans are planted to meet market demands. More baby lima beans are grown than Fordhook or speckled types. Baby lima beans produce consistently higher yields than the heat-sensitive Fordhook types, although consumer demand for Fordhook types is significant. Speckled types fulfill a regional market demand, primarily in the southern United States.

Characteristics that influence variety selection are consistent yield, disease resistance, quality, and availability. The varieties listed in Table 1 are used in several production regions. Lima bean yield was found to be closely related to plant size (Smittle, 1986). Varieties that set more pods higher on the plant are also more-efficiently harvested (Kee and Glancey, 1996). Maturities (days from planting) are given on the best evidence from the Delaware variety trials and commercial experience in Delaware. Maturity can vary from season to season and even within a season, depending on conditions. For planning purposes, the relative maturity differences between varieties are important. There are also several privately owned varieties that are planted exclusively for certain processing companies.

Plantina date, rate, and spacina. Lima beans are planted in scheduled plantings, coordinated by processors, to accommodate orderly flow of raw product. These schedules are based on the acreage that can be harvested per day. The growers with their own harvest equipment must coordinate their planting and harvest schedules with processors.

Baby lima beans may be planted in Delaware between 15 May and 20 July. Fordhook lima beans are planted from 1 June to 10 July. Fordhook types require warmer soil for optimum germination, and their longer maturity increases the risk of frost before are harvest. Minimum soil temperature for best germination of all types is $65^{\circ} \mathrm{F}$. Plantings that mature in August and early September are subject to reduced yields from heat and drought.

Depth of planting is critical for obtaining optimum populations and uniform stands. Lima beans should be planted no deeper than $\mathbf{1 . 5}$ inches, with 1 to 1.5 inches the optimum depth for most conditions. Extremely dry soils may warrant irrigation to provide optimum conditions for germination.

Baby and Fordhook lima beans can be

Table 1. Descriptions of commercially available lima bean varieties.

\begin{tabular}{|c|c|c|c|c|c|}
\hline Variety & Type & $\begin{array}{c}\text { Maturity- } \\
\text { days to harvest }\end{array}$ & $\begin{array}{l}\text { Downy mildew } \\
\text { resistance }\end{array}$ & Source & Comments \\
\hline M-15 & Baby & 80 & $\mathrm{~A}, \mathrm{~B}, \mathrm{C}, \mathrm{D}$ & Sacramento Valley, Milling & $\begin{array}{l}\text { Its small size and tendency to set pods on } \\
\text { the ends of raceme can reduce harvest } \\
\text { recovery with pod-stripper combines. }\end{array}$ \\
\hline Eastland & Baby & 82 & $\mathrm{~A}, \mathrm{~B}, \mathrm{C}, \mathrm{D}$ & Several & $\begin{array}{l}\text { Closely related to } \mathrm{M}-15 \text {. Has a } \\
\text { more upright plant architecture, more } \\
\text { conducive to harvest by pod-stripper } \\
\text { combine. }\end{array}$ \\
\hline $8-78$ & Baby & 85 & $\mathrm{~A}, \mathrm{~B}, \mathrm{C}, \mathrm{D}$ & Ben Fish Seed Co. & $\begin{array}{l}\text { Larger plant type. Consistently good } \\
\text { yielding variety. }\end{array}$ \\
\hline 184-85 & Baby & 86 & $\mathrm{~A}, \mathrm{~B}, \mathrm{C}, \mathrm{D}$ & Ben Fish Seed Co. & $\begin{array}{l}\text { Larger plant type that sets more pods in } \\
\text { the top of the plant. A good yielding } \\
\text { variety. }\end{array}$ \\
\hline Jackson Wonder & Speckled & 85 & None & Several & $\begin{array}{l}\text { Speckled bean type, with morc } \\
\text { heat resistance than others. }\end{array}$ \\
\hline 16607 & Baby & 83 & $\mathrm{~A}, \mathrm{~B}, \mathrm{C}, \mathrm{D}$ & Sacramento valley, Milling & $\begin{array}{l}\text { New Variety that has demonstrated good } \\
\text { yield potential in trials. }\end{array}$ \\
\hline Packcrs & Baby & 85 & None & Ferry-Morse & $\begin{array}{l}\text { Has demonstrated good yield potential } \\
\text { in later plantings in Delaware when } \\
\text { conditions are cooler. }\end{array}$ \\
\hline F1072 & Fordhook & 95 & $\mathrm{~A}, \mathrm{~B}, \mathrm{C}$ & Several & $\begin{array}{l}\text { Standard green-seeded Fordhook. } \\
\text { Sensitive to heat. }\end{array}$ \\
\hline $90-1$ & Fordhook & 95 & $\mathrm{~A}, \mathrm{~B}, \mathrm{C}, \mathrm{D}$ & USDA release & $\begin{array}{l}\text { Yields equal to F1072. Has a larger berry } \\
\text { size. }\end{array}$ \\
\hline F5516 & Fordhook & 95 & $\mathrm{~A}, \mathrm{~B}, \mathrm{C}, \mathrm{D}$ & Sacramento Valley, Milling & $\begin{array}{l}\text { Has outyielded F1072 in trials. } \\
\text { Recommended for trial use. }\end{array}$ \\
\hline
\end{tabular}


planted in rows 30 to 36 inches apart. Baby lima beans should be planted at rates to give 9 to 12 plants/yard and Fordhook lima beans 6 to 9 plants/yard. Research has been conducted on the effect of narrow-row spacing (Sirait et al., 1994). Excellent weed control and irrigation are necessary to produce and harvest lima beans successfully in narrow rows, i.e., rows less than 24 inches. Even when this has been achieved, there has been no clear yield advantage in varied commercial settings to advocate narrow-row lima bean production.

Seed size varies among varieties and must be taken into account when determining seed needed per acre. Baby lima bean varieties range from 1150 to 1450 seeds $/ \mathrm{lb}$. Fordhook varieties range from 440 to 550 seeds $/ \mathrm{lb}$. Hence planting rates for baby lima beans in 30 -inch rows can range from 61 to $48 \mathrm{lbs} /$ acre.

Weed control and cultivation. Good weed control is essential to achieve good yields and facilitate harvest operations. Weeds compete with the lima bean plant for nutrients, water, and sunlight. Heavy weed populations may create environments more favorable for plant diseases and insects. Weedy fields at harvest reduce raw product recovery by harvesters and generate more trash in the harvested product. Handling trash reduces efficiency and adds cost during raw product preparation at the processing plant (Glancey et al., 1995).

Cost-effective weed control relies on the use of herbicides. Preemergence treatments of metolachlor, alachlor, or trifluralin are often used to achieve control of annual grasses and some broadleaf weeds. Imazthepyr is labeled in certain states for preemergence control of many broadleaf weeds (Kee and Rider, 1988). Postemergence control of grasses can be achieved with sethoxydim, while postemergence control of many broadleaf weeds can be achieved with bentazon, except in California (Kee et al., 1996).

Mechanical cultivation is a major part of a weed-control program. Proper cultivation will not only enhance weed control, but can improve recovery of raw product during harvest, thus increasing the harvested yield per acre. Cultivating too deeply, or creating a ridge that restricts the harvester's ability to harvest the lower portion of the plant, will reduce yields. To improve harvest recovery, growers are encouraged to cultivate in a way that leaves the field as flat as possible, either by cultivating slowly or with equipment like s-tine cultivators designed to maintain level fields (Glancey et al., 1995).

Horsenettle (Sol-anum carolinese L.), lance leafground cherry (Physalis lancefiolia), black nightshade (Solanum nigrum), hairy nightshade (Solanum sarrachoides), yellow nutsedge (Cyperus esculentus), and morningglory (Ipomea sp.) are major weed problems, nationally. These weeds not only reduce yields through competition, but can also reduce quality through fruit or weed seed contamination in the raw and processed product. Nightshade species are particularly important because of the toxicity of their berries and the potential of staining the light-skinned lima beans. Growers face economically significant grade reductions and processors face costly contamination removal procedures when confronted with these situations. Registered herbicides often do not adequately control these weeds. Postharvest applications of glyphosate or dicamba may offer opportunities to control horsenettle in the future, if application timing is appropriate in relation to the weed stage and the time of year.

Iraigation. Lima beans are routinely irrigated in California and Delaware. Furrow irrigation is the predominant system in California. Sprinkler irrigation is the only type used in Delaware. Research in Delaware indicated a positive response from irrigation, especially sandy soils (Vittum et al., 1963; Ritter and Scarborough, 1990). However, temperatures above $90^{\circ} \mathrm{F}$ can override possible benefits of irrigation by causing blossoms to drop.

In Delaware, later plantings of lima beans usually experience cooler conditions and more rainfall in late August and September than in earlier plantings. About $30 \%$ of the lima bean acreage is not irrigated in Delaware. In Minnesota, Wisconsin, and Illinois, irrigation is generally not used. Growers in all regions face the management decision of what crops offer the best potential return from irrigation. Although there is strong evidence of lima bean response to irrigation, other crops may offer better use of irrigation than lima beans. However, even in lateseason conditions, irrigation reduces risk and offers higher yield potential than nonirrigated production.

Disease Problems and control. Downy mildew (Pbytophthora phaseoli Thaxt.) has been a major disease problem of lima beans grown in the humid regions of the eastern United States since it was first reported in Connecticut in 1889 (Fig. 5). Major yield losses due to downy mildew occurred periodically in New Jersey and Delaware before 1960. During the 1930s, one processor was forced to move from New Jersey to a region in Delaware where lima beans had not been produced. Other firms were forced out of business because of this disease. As late as 1958, Delaware producers experienced a loss of more than 2 million lbs of beans from 11,675 acres (App, 1959). 
Fig. 6. Side-view schematic of a typical pod-stripper combine. Note the cab, frame, and drive wheels have not been included.
Four lima bean strains, from India, Guatemala, southeastern United States, and California, were found to be resistant to downy mildew. The inheritance of downy mildew is controlled by a single dominant gene (Wester and Cetas, 1959). In 1958, Thaxter was the first commercially released variety with resistance to downy mildew (App, 1959). Genetic resistance has successfully reduced the incidence of this disease (Wester and Cetas, 1959). However, soon after the release of Thaxter, which is resistant to one strain, additional strains of downy mildew were found, making development of varieties with resistance critical to profitable production. Four strains (A, $\mathrm{B}, \mathrm{C}$, and $\mathrm{D}$ ) of downy mildew are present in the mid-Atlantic region (Thomas and Blount, 1976).

During the 1950 s, conditions that were conducive to downy mildew were studied in Delaware (Hyre, 1957; Hyre and Cox, 1953). Conditions for disease development are favorable when fields receive 1.2 inches or more of rain within 7 days and when the average daily temperature during this period is $78^{\circ} \mathrm{F}$ or less. If a period of $90^{\circ} \mathrm{F}$ occurs, the cycle is broken, and an additional 7-day period with the above weather conditions is necessary to start inflection. Periods of fog or heavy dew can lower the amount of rain necessary for infection. Since environmental conditions vary from field to field and in different locations within a field, the above information is provided only as a guideline. Fields that are not rotated and are planted to susceptible varieties should be scouted regularly for disease. When weather conditions are favorable for disease or when disease is first observed, treatments of tri-basic copper sulfate are useful for control. Historically, maneb fungicides were used, but these fungicides are no longer labeled in the United States.

Rhizoctonia and Pythium are the major root-rot causal organisms in Delaware. Crop rotation with nonlegume crops is important to minimize this disease. Plowing under previous crop residue rather than disking helps reduce the incidence of these diseases. Ridomil PC11, which contains metalaxyl (which controls Pythium) and terrachlor (which controls Rbizoctonia) are often used. Ridomil PC1l is strongly recommended on late plantings when hot, moist conditions can favor problems with Pythium. Rhizoctonia can be pervasive in many fields as a result of many years of legume cropping. Rbizoctonia usually does not kill the plant, but the distinct reddishbrown lesions on the stem are easily seen and reduced growth can result.

White mold (Sclerotinia) can be found

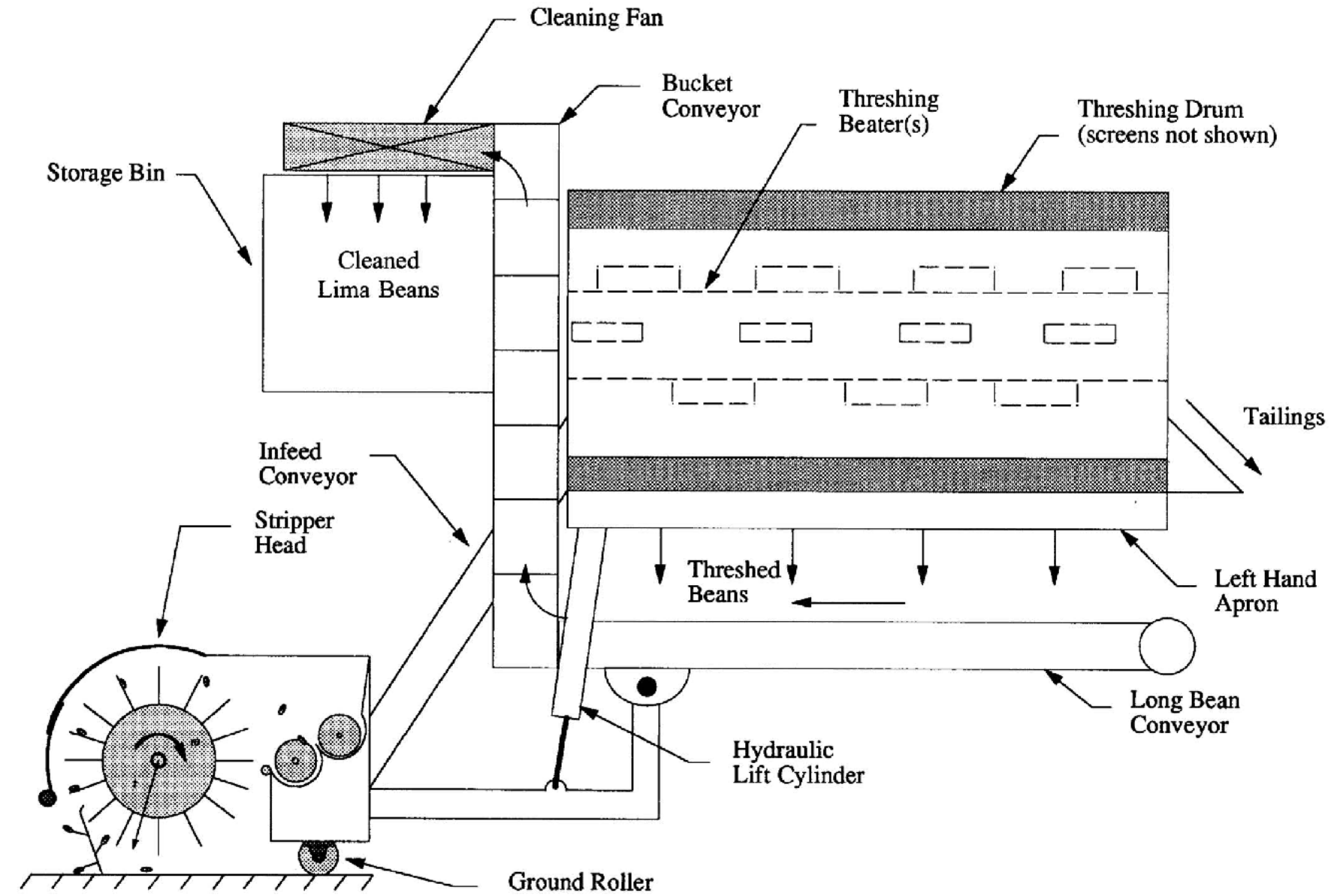


in small areas of late lima bean plantings, but is usually not an economic problem. Anthracnose and gray mold (Botrytis) can also attack lima beans, but are rarely an economic problem in Delaware.

InSECT PROBLEMS AND CONTROL. Insect pests that attack lima beans include cutworms, tarnished plant bugs, mites, aphids, leafhoppers, lygus bugs, Mexican bean beetles, corn earworms, and fall armyworms. Because significant acreage of lima beans are planted in June and July, late-season podworms (corn earworms and fall armyworms) are the major economic pests. Infestations can be severe in some years.

For baby lima beans, treatment is recommended when corn earworm populations exceed one larvae / 6 feet of row from the late flat pod stage to harvest. For Fordhook lima beans, treat when corn earworm populations exceed two larvae / 6 feet of row up to 4 weeks from harvest and three larvae/ 6 feet of row thereafter. For baby and Fordhook lima beans, treatment should be timed when $50 \%$ or more or fall armyworm larvae reach 0.5 inch or longer. Treating too early for corn earworm and fall armyworm will eliminate natural control and may result in additional sprays. Methomyl is recommended for corn earworm and fall armyworm control (Kee et al., 1996).

Nematode control. Various nematode genera can infect lima beans. Southern root- knot nematode can be damaging. Crop rotation is useful in managing this pest. Fumigation is effective, but expensive. Ethoprop can be used at planting. It must be applied in a 12 inch band over the row.

Soybean cyst nematode is present in lima bean acreage of Delaware. Lima beans are resistant to this nematode at present, but green beans (Phaseolus vulgaris L.) are not. Growers who rotate with soybeans (Glycine max) or green beans should be alert to the possibility of potential problems with fields infested with soybean cyst nematodes. In California, root-knot nematodes are occasionally a problem.

Soil sampling for nematode detection is strongly recommended in the fall before planting lima beans. A nematode assay taken at this time will have the best chance of detecting damaging levels of plant parasitic nematodes, especially southern root-knot nematode (Kee et al., 1996).

\section{Harvesting lima beans}

All lima beans grown for processing are harvested mechanically, most with pod-stripper combines, which have largely replaced the pull-type combines. Pull-type combines require cutting and windrowing of the plants at harvest and threshing the whole plant. Pod-stripper combines harvest primarily pods with significantly less plant material. Advances over the last 2 decades in harvesting of lima
Fig. 7. Rear-view schematic of the threshing beater and cleaning apron operations on a typical podstripper combine.

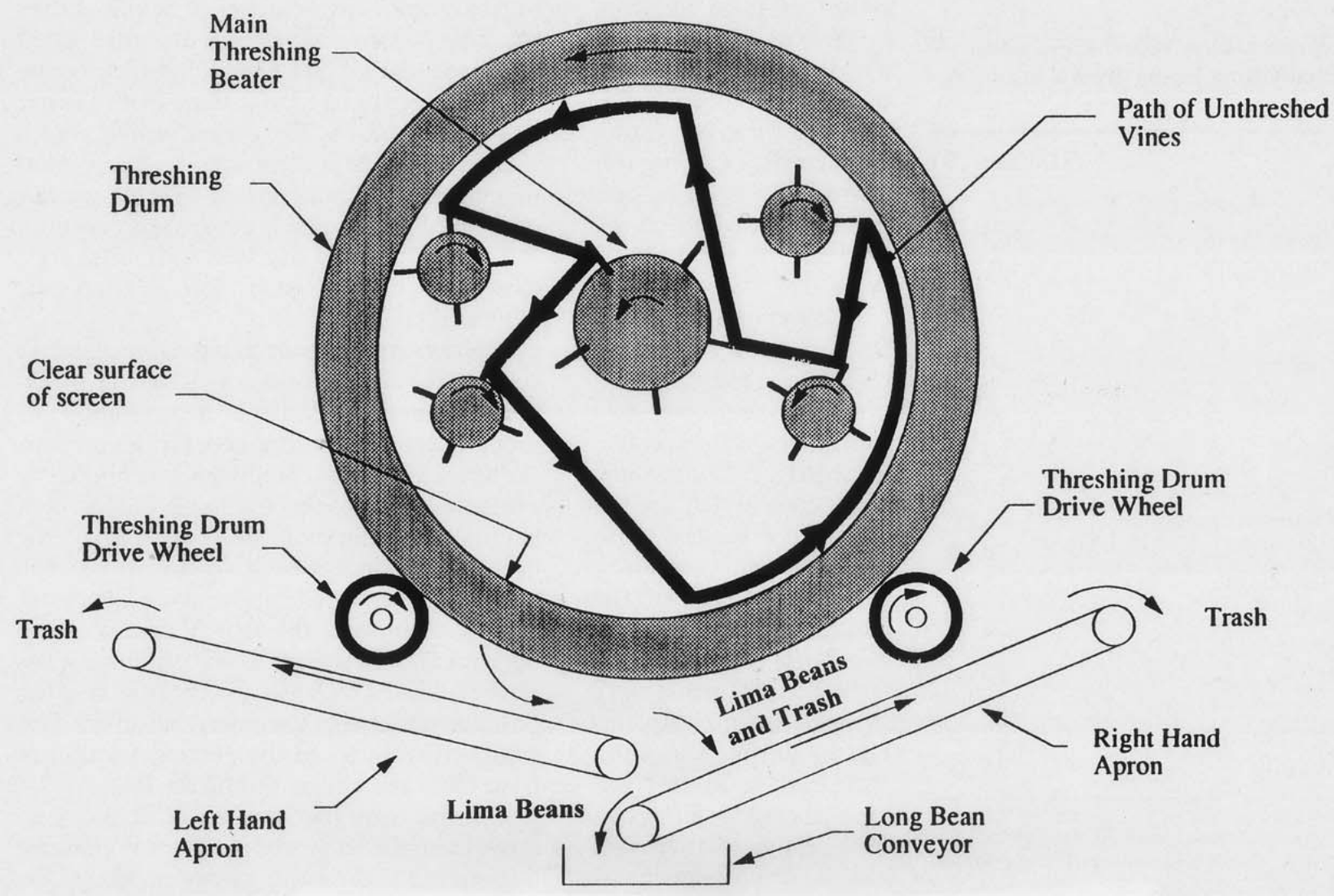


beans (and peas) include multi-beater threshing systems for additional throughput capacity, six-wheeled and tracked harvesters for improved performance in wet conditions, electrohydraulic systems, which provide the operator with increased control of key machine functions, as well as the stripper head for once-over harvesting (Figs. 6 and 7). Before 1994, little work had been done with pod-stripper combines in any crop to quantify the effects and interactions of harvester operation, growing practices, and crop variety on harvest loss, product cleanliness, and product processing.

In 1994, a 2-year study was initiated in Delaware to evaluate current technology and practices for growing and harvesting lima beans for processing. The objectives of the study were to measure harvest losses and product quality under a wide range of practices and conditions in the mid-Atlantic re'gion, determine interactions of cultural practices, crop varieties, harvester type and combine operating parameters with harvest loss and harvested product quality, and develop recommendations to improve production and harvesting efficiency.

More than 90 harvester evaluations tests have been performed on pod-stripper combines including machines manufactured by FMC, Inc., Hoopeston, Ill., Chis-holm-Rider Co. Inc. (no longer in business); Pic-Ryte, Walla Walla, Wash., Hamachek Machine Co., Kewaunee, Wis., and Byron Enterprises, Byron, N.Y. In addition,

Table 2. Representative returns and costs per acre of baby lima beans grown in Delaware.

\begin{tabular}{lr}
\hline & Dollars (\$) \\
\hline Returns $^{z}$ & \\
$3000 @ \$ 0.1675 / \mathrm{lb}$ & 502.50 \\
$2000 @ \$ 0.1675 / \mathrm{lb}$ & 335.00 \\
Costs & \\
Nitrogen & 19.50 \\
Mixed fertilizer & 30.80 \\
Lime & 9.60 \\
Secd & 34.50 \\
Herbicide & 12.53 \\
Plowing & 13.00 \\
Disk and harrowing & 11.00 \\
Planting & 10.00 \\
Chemical application & 18.00 \\
Cultivation & 12.00 \\
Insccticide & 12.00 \\
Irrigation & 50.00 \\
Total & 238.93 \\
Net return @ 3000 lb & 263.57 \\
Net return @ 2000 lb & 96.03
\end{tabular}

${ }^{2}$ Average contract price.

${ }^{y}$ Costs reported in Vegetable and Agronomic Crop Budget, Ext. Bul. 152, Delaware Cooperative Extension, Univ. of Delaware, Newark. nificant factors that effect lima bean recovery at the combine head are field levelness, the relationship between combine ground speed and picking reel speed, and lima bean variety.

Field levelness across the width of the combine head significantly affects head loss. Field tests indicate unlevel ground conditions resulting from mechanical cultivation for weed control doubled the amount of head loss compared to level ground. Excessive ground speed, multiple passes with the cultivator, and improper cultivator configuration will contribute to unlevel ground. Weed control programs that incorporate cultivation practices that result in minimal ground disturbance and leave a level ground surface will help maximize recovery with pod-stripper combines.

Experiments to determine optimal combine operating speeds clearly indicate higher head losses occur at lower ground speeds. Specifically, loose pod loss increases at speeds less than 0.75 miles/hour resulting in excessive loss at the head. This loss can be reduced with lower picking reel speeds; however, reducing ground speed below 0.75 miles/hour does not improve recovery. In general, ground speed should be limited by the threshing and cleaning capacities of the combine and not reduced to improve product recovery (Glaney et al., 1996).

Field tests verified that some lima bean varietics are better suited than others for mechanical harvesting with pod-stripper combines. From measurements of field loss over the last 2 years, varieties with small plant structures like Maffei 15 exhibited twice the head losses compared to varieties with a larger structure like 8-78. The higher head loss with smaller varieties is attributed to the fundamental plant architecture in which a greater portion of the pod set is close to the ground. Even with properly adjusted combines, pods close to the ground will be difficult to recover (Kee and Glancey, 1996).

Hakvested product quality. Average trash content for all field tests was $13 \%$ over the 2 year test period. While over-threshing, improper apron angle and tension, excessive weeds, and incorrect header height all contributed to excessive trash, proper cleaning fan adjustment is critical to minimize trash content in the harvested product. Tests have shown that small changes in fan speed can result in significant bean loss through the fan. Maximum trash removal with the least amount of lima bean loss can be achieved with proper distribution of the product under the secondary fan inlet. This approach will expose the greatest portion of trash that can be removed by the fan.

Some trash particles are difficult to remove from the harvested product. Weeds like horsencttle and morningglory produce ber- 
ries or seeds that are similar in size or color to lima beans. Weed seeds as well as other foreign materials detected can result in penalty or price reduction to the grower, including outright rejection of the load if nightshade is detected. Removing these weed seeds with the cleaning systems on the combine or with color sorters in the processing plant is difficult. Many times, loads of lima beans must be resorted by hand when any Horsenettle berries, nightshade, and/or morningglory weed seeds are detected during a quality inspection. At present, the best method to reduce berries and weed seed content from the harvested product is a good weed-control program (Glancey et al., 1996).

Overall, a systematic approach to production that includes proper variety selection, field preparation, cultivation, and combine adjustment and operation will minimize harvest loss and maximize quality. Consideration of all these factors will improve profitability for growers and processors.

\section{Economics and marketing}

Processed lima beans are marketed as either a canned or frozen product. Canned lima beans are distributed for retail and institutional use, either as a single product or mixed with other vegetables. Often lima beans are used as in ingredient in soup products. Frozen lima beans are distributed for retail, institutional, or industrial use for repacking in soups, frozen prepared meals, and other mixed vegetable products.

In 1995, the average yield for the entire United States was 1.36 tons/acre, with a value of $\$ 31,240,000$ (USDA, 1996). In 1994, the latest year reported by the National Agricultural Statistics Service, lima beans were planted on 10,200 acres in Delaware. Yields averaged $2000 \mathrm{lbs} / \mathrm{acre}$, generating a total production of 20.4 million lbs of lima beans. With an average price of $\$ 335 /$ ton, a cash income to Delaware producers of more than $\$ 3.4$ million was generated (Tarburton et al., 1995).

Table 2 lists representative costs, yields, and prices for baby lima beans in Delaware. This is designed to be used as a guide for producers and processors as they plan production. These are averages, growers must be better than average to be profitable.

Although there is considerable competition from other lima bean producing regions, those regions have limited acreage and are distant. Delaware has a long tradition of lima bean production and the grower-processor infrastructure to support it. The relative uniqueness of the crop gives area processors a product line that, while profitable in itself, also helps defray overhead and fixed costs associated with processing of other vegetables. In short, lima beans bring a stability to
Delaware's vegetable processing industry. However, challenges persist. Lima beans yields on a per-acre basis are lower in Delaware than in all other production areas. Difficulties that must be overcome include serious production issues related to disease, insect, and weed control; developing varieties better adapted to Delaware conditions; enhancing harvest recovery; and reducing trash content in the raw product to increase efficiency and decrease wastewater production at the processing plant. Such improvements would reduce costs, mitigate negative impacts on the environment, and reduce the regulatory burden. Per capita consumption of lima beans is declining. Consumer education programs designed to inform the public about the nutritional and health advantages associated with lima beans would be beneficial to the industry and consumers alike. Increased consumption, coupled with improved varieties, advanced cultural practices, and more efficient harvest methods, can enhance the profitability for growers and processors.

\section{Literature cited}

Andrews, F.S. 1935. Physiological factors associated with the fruiting habits of the bush lima bean. Proc. Amer. Soc. Hort. Sci. 33:473-476.

App, F. 1959. The history and economic importance of the lima bean downy mildew disease. Plant Dis. Rpt., Crops Res. Div., Agr. Res. Serv., USDA. Suppl. 257, 15 Junc.

Corder, H.B. 1933. External and internal factors affecting blossom drop and set of pods in lima beans. Proc. Amer. Soc. Hort. Sci. 30:571-576.

Fisher, V.J. and C.K. Weaver. 1974. Flowering, pod set, and pod retention of lima bean in response to night temperature, humidity, and soil moisture. J. Amer. Soc. Hort. Sci. 99:448-450.

Glancey, J.L., W.E. Kee, T.L. Wootten, and B.C. Postles. 1995. Harvesting of green peas and lima beans for processing. Proc. Amer. Soc. Agr. Eng. Annu. Mtg. Paper 95-1773.

Glancey, J.L., W.E. Kee, and T.L. Wootten. 1997. Machine harvest of lima beans for processing. J. Veg. Prod. (In Press.)

Hendry, G.W. 1918. Bean culture of California. Calif. Agr. Expt. Sta. Bul. 294., Univ, of California, Berkeley.

Hyre, R.A. 1957. Forecasting downy mildew of lima bean. Plant Dis. Rpt. 41(1):7-9.

Hyre, R.A. and R.S. Cox. 1953. Factors affecting viability and growth of Phytophthora phaseoli. Phytopathology 43:419-425.

Kee, W.E. and L. Rider. 1988. Efficacy, phytotoxicity, soil residual of imazathepyr on peas and lima beans. Proc. Northeastern Weed Sci. Soc. 42:19199.

Kee, W.E., J.L. Glancey, and T.L. Wootten. 1996. 
Successful lima bcan production in Delaware. Veg. Fact Sheet 6, Univ. of Delaware, Newark.

Kee, E., R.P. Mulrooney, D. Caron, and J. Whalen. 1996. Commercial vegetable production recommendations. Ext. Bul. 137, Univ. of Delaware, Newark.

Kee, W.E. and J.L. Glancey. 1996. Rating the pod setting habit of lima bean cultivars to improve harvest recovery with the pod stripper combine. Proc. Amer. Soc. Hort. Soc. Annu. Mtg. Lexington, Ky., Abstr. 610.

Lambeth, V.N. 1950. Some factors influencing pod set and yield of the lima bean. Res. Bul. 466, Univ. of Missouri College of Agriculture, Columbia.

Lyman, J.M., J.P. Baudoin, and R. Hidalgo. 1985. Lima bean (PhaseoluslunatusL.), p. 477-519. In: R.S. Summerfield and E.H. Roberts. (eds.). Grain legume crops. Collins, London.

Mackie, W.W. 1943. Origin, dispersal, and variability of the lima bean, Phaseoluslunatus. Hilgardia 15:1-29.

Nienhuis, J., J.B. Dos Santos, J. Tivang, and P. Skorch. 1993. Organization of lima bean (Phaseolus lunatus L.) germplasm based on RAPD banding patterns. Proc. Bean Imp. Coop., 2-4 Nov.

Ritter, W.F. and R.W. Scarborough. 1990. Irrigation management of lima beans. Amer. Soc. Agr. Eng. 1990 Annu. Summer Meeting Paper 902006.

Sirait, Y., W.G. Pill, and W.E. Kee. 1994. Lima bean (Phaseolus lunatus L.) response to irrigation regime and plant population density. HortScience
29:71-73.

Smittle, D.A. 1986. Influence of cultivar and temperature on lima bean yield and quality. J. Amer. Soc. Hort. Sci. 11:655-659.

Stavely, J.R. 1991. Lima bean (Phaseolus lunatus L.) development at Beltsville. Annu. Rpt. Bean Imp. Coop. 34:155-56.

Tarburton, J.F., T.W. Feurer, and D.M. Bay. 1995. Delaware agricultural statistics summary for 1994. Delaware Dept. of Agr.

Thomas, C.A. and V.L. Blount. 1976. Race D of Phytophthora phaseoli. Plant Dis. Rpt. 60:308.

U.S. Department of Agriculture. 1996. Lima beans for processing: Area planted and harvested, yield, production, and value by utilization 1993-95. Natl. Agr. Stat. Serv. Veg. Situation, January.

U.S. Department of Agriculture. 1996. Bean market news. vol. 32, no. 10. Greeley, Colo.

Vittum, M.T., R.B. Alderfer, B.E. Janes, C.W. Reynolds, and R.A. Struchtemeyer. 1963. Crop response to irrigation in the Northeast. Bul. 800, New York State Agr. Expt. Sta., Geneva.

Wester, R.L. and R.D. Cetas. 1959. Breeding lima beans for resistance to downy mildew. Plant Dis. Rpt. Suppl. 257, Crops Res. Div., Agr. Res. Serv. 15 June.

Wester, R.L. 1965. Grecn cotyledon in lima bcans, its origin and development. SeedWorld 96(11):30.

Wootten, T.L. 1995. The effects of heat stress on retention and abscission of lima bean reproductive structures. MS thesis. Univ. of Delaware, Newark. 